\title{
Induction and differentiation of reproductive buds in Coffea arabica $\mathrm{L}$.
}

\author{
Nidia Majerowicz $^{1^{*}}$ and Maro R. Söndahl ${ }^{2}$
}

${ }^{1}$ Universidade Federal Rural do Rio de Janeiro, Departamento de Ciências Fisiológicas, Rodovia BR 465, Km 07, CEP 23890-000, Seropédica, RJ, Brasil; ${ }^{2}$ Fitolink Corp., P.O. Box 669, Mount Laurel, NJ 08054 USA. *Corresponding author: nidia@ufrrj.br

Received: 23/04/2005, Accepted: 17/06/2005

The induction and differentiation phases of reproductive buds of Coffea arabica L. have not received much attention. In the present paper, axillary buds from five plagiotropic branches that developed in the same growing season without fruits (1st crop branches), and from green segments of five recently grown plagiotropic branches with fruits (2nd crop branches), were collected every two weeks during successive inductive months of the year. This study was carried out with adult arabica trees, Catuaí Vermelho cv. IAC 81, cultivated under normal farming conditions in the region of Campinas, SP, Brazil (2254' Lat. S). Slides of longitudinal-axial sections of 10-12 $\mu \mathrm{m}$ thickness were mounted for the characterization and quantification of histological stages of bud differentiation. The results indicate that the regulatory signals controlling the phases of induction and differentiation of floral buds are distinct, and that there are differences in the response between branches with and without fruits. In the case of 1 st crop branches (no fruits present), induction of floral buds took place in January and February, whereas floral bud differentiation was observed during the months of March and April. In 2nd crop branches (fruits present), the induction of floral buds was observed during any month of the year provided that they had already overcome their juvenile state (OctoberJuly, in this study). In these 2nd crop branches, the flower bud differentiation was only observed after harvesting all pre-existing fruits of each branch (after May, in this study), which suggests that floral bud differentiation in Arabica coffee is influenced by the source-sink relationship, i.e. by the presence of developing fruits within each plagiotropic branch.

Key words: arabica coffee, floral differentiation, floral induction, flower buds, histological differentiation, reproductive development.

Indução e diferenciação de gemas reprodutivas Coffea arabica L.: As fases de indução e diferenciação de gemas reprodutivas têm sido pouco estudadas em Coffea arabica L. No presente estudo, gemas axilares de cinco ramos plagiotrópicos formados na estação de crescimento recente e sem frutos ( $1^{a}$ produção) e de segmentos recentes de cinco ramos plagiotrópicos com frutos ( $2^{\text {a }}$ produção) foram coletadas quinzenalmente em diferentes épocas do ano. Foram utilizados cafeeiros arábica adultos var. Catuaí Vermelho, cultivados nas condições ambientes de Campinas (latitude 2206'LS), SP, Brasil. Lâminas contendo cortes longitudinais-axiais com cerca de 10-12 $\mu \mathrm{m}$ de espessura foram analisadas para a caracterização e quantificação dos estadios de diferenciação histológica. Os resultados obtidos indicam que os sinais que regulam a indução e a diferenciação das gemas florais são distintos, bem como existem respostas diferentes para ramos de $1^{\mathrm{a}}$ e $2^{\mathrm{a}}$ produção. Para a região de Campinas, em ramos de $1^{\mathrm{a}}$ produção (sem frutos), a indução de gemas florais ocorreu nos meses de janeiro-fevereiro. A diferenciação das gemas florais foi observada a partir dos meses de março e abril. Nos ramos de $2^{\mathrm{a}}$ produção (com frutos), a indução floral ocorreu durante todos os meses, uma vez superado o estado juvenil (outubro-julho, neste estudo). Nestes ramos com frutos, a diferenciação das gemas florais ocorreu somente após a colheita dos frutos pré-existentes nos ramos (a partir de maio), sugerindo que a diferenciação floral estava sendo influenciada pelas relações fonte-dreno do cafeeiro. A diferenciação floral em ramos contendo frutos mostrou-se intensamente influenciada pela presença de frutos em desenvolvimento.

Palavras-chave: café arábica, diferenciação floral, diferenciação histológica, desenvolvimento reprodutivo, gema floral, indução floral. 


\section{INTRODUCTION}

Flower bud formation requires a series of changes in the differentiation pattern of apical or axillary buds (Thomas and Vince-Prue, 1997). Flower bud development is a process with a high level of complexity characterized by two distinct physiological phases: (a) bud initiation; and (b) floral bud development (Bernier, 1988). Internal and external signals have a fine regulatory function on the timing of flowering (Bernier et al., 1993; McDaniel, 1996). According with McDaniel et al. (1992), once a meristem has been determined to be reproductive it follows its program even in the absence of inducing stimuli. On the other hand, the capacity to respond to induction signals for reproductive development depends on the physiological state of the plant or some plant part. The transition between the juvenile and adult phase is characterized by changes in meristem sensitivity to internal and external signals of flower induction. At maturity, buds become competent to respond to induction stimuli (McDaniel et al., 1992).

Little is known about the induction and development process of reproductive buds in Coffea arabica L. Most of the information available covers the more advanced developmental phases of reproductive buds. Furthermore, experiments are rarely carried out under controlled environmental conditions for perennial species, especially for coffee because of its slow growth pattern.

Three classic studies, carried under greenhouse conditions, showed that the formation of reproductive buds in young $C$. arabica cv. Bourbon plants was induced by shortdays. The critical photoperiod was determined to be between 13-14 hours (Franco, 1940; Piringer and Borthwick, 1955; Went, 1957). In studies with adult coffee plants grown under field conditions in Ruiru, Kenya (1 ${ }^{\circ} 08^{\prime}$ S), Cannel (1972) concluded that despite coffee plants behaving as short-day plants their sensibility sensitivity to photoperiod was very low. According with to Cannel (1972), only quantitative differences were observed between control plants (12 h) and plants under different photoperiodic treatments (interruption of nights by $3 \mathrm{~h}$ or $15 \mathrm{~min}$ ). Among annual species (Labouriau, 1969; Zeevaart, 1976; Thomas and Vince-Prue, 1997) and perennial species (Jackson and Sweet, 1972) photoperiodic requirements for inducing the development of floral buds are altered, or even eliminated, when plants are kept under infra or supra optimum air temperatures.

In equatorial regions, where photoperiod is continuously inductive to coffee plants, the period of more intense differentiation of flower buds is attributed to lowering of temperature (Wormer and Gituanja, 1970a) and the presence of moderate water stress (Trojer, 1956). Many authors related the period of intense flower bud differentiation in $C$. arabica and C.canephora to the previous vegetative period (Moens, 1962; Boyer, 1969; Wormer and Gituanja 1970a, 1970b; Camayao et al., 2003). In Ruiru (Kenya $1^{\circ} 08^{\prime} \mathrm{S}$ ), the flowering cycle was only modified by a pruning schedule, delayed harvest on weak plants, or by insufficient rainfall during the vegetative growth period (Wormer and Gituanja, 1970a,b).

In the foliar axils of lateral coffee branches, 4-5 buds are present in a linear sequence, designated by Moens (1963) as "serial buds". The most developed bud of this series, the first formed, can originate a new lateral branch or an inflorescence. Histological analysis allows precise evaluation the timing that vegetative buds begin the transition to the reproductive phase (Moens, 1963; Barros et al., 1978).

The present study has the objective of identifying the timing when axillary buds begin their reproductive differentiation process and to characterize the dynamics of the differentiation process in adult coffee plants, growing under field conditions in the region of Campinas, SP, Brazil (22 $54^{\prime}$ Lat. S).

\section{MATERIAL AND METHODS}

This study was carried in 1980-1981. Adult plants (6-7 years old) of Coffea arabica L. cv. Catuai Vermelho IAC 81 (H-2077-2-5-81), cultivated at the Experimental Center of the Institute of Agronomy at Campinas (IAC), São Paulo State, Brazil were utilized in this study. Two groups of lateral (plagiotropic) branches were analyzed: (a) branches without fruits, collected in the upper third portion of coffee plants, formed during the same vegetative period; and (b) recent segments of lateral branches bearing fruits in their older leaf axils, formed in the previous vegetative period.

During the first 2 years of this study (years I and II) only "1st crop branches" (fresh-formed branches) were studied. In the subsequent years III and IV, "2nd crop branches" (these bearing fruits in older leaf axils) were studied. During the period between Febr.15 - April 24/Year-I and between Jan.06 - July 15/Year-II, bi-weekly harvesting of five "1st crop lateral branches" were made. After removal of stipules, the first serial buds, denominated as G1, were removed and fixed in FAA 50\%. Using the branch apex as reference, G1 buds were collected from 4 th -9 th leaf axil position.

For recently grown segments of " 2 nd crop branches", bi-weekly harvesting of axillary buds were made during 
Nov.01/Year-III - June 30/Year-IV. G1 buds were removed from young nodes (2nd - 3rd pair of leaves) and from older nodes located at the 4 th -7 th leaf pair, starting from the apical portion of the branch, and fixed in FAA $50 \%$. Slides $\mathrm{f}$ axial-longitudinal sections were prepared as described below and then submitted to histological observation. Fixed buds were washed in $70 \%$ ethanol, dehydrated through a series of tertiary butyric alcohol solutions and then included in Parafilm. Axial-longitudinal sections 10-12 $\mu \mathrm{m}$ thick were prepared and stained with $0.5 \%$ safranin and fast-green. The duration in the safranin solution varied according to the developmental stage of the buds. For buds of $2 \mathrm{~mm}$ in size, or smaller, a safranin bath of $15 \mathrm{~min}$. was established, whereas larger buds were kept 2-3 min. in the safranin solution.

A total of 13-34 G1 buds were studied for each collection time over years I and II, and 22-53 buds were analyzed at each collection time over years III and IV. This large number of buds allowed the quantification of the evolution of several bud differentiation phases at the histological level, over the collection periods specified in this study for Years I - IV.

\section{RESULTS AND DISCUSSION}

Histological differentiation of flower buds: Floral meristems are easily distinguished from vegetative meristems due to their size difference. In general, floral meristems are larger and broader than the vegetative ones. This size difference is caused by a marked increase in the frequency of cell division in the central meristematic zone during the transition period from vegetative to floral stage (Fosket, 1994). In C.canephora, when the axillary bud follows the reproductive path, the central cells of the apical portion undergo frequent periclinal and anticlinal divisions resulting in the broadening and enlargement of the apical zone (Moens, 1963).

Non-differentiated axillary buds (at the vegetative state) are characterized by a typical conical and narrow apex inserted between the foliar and stipule primordia (Stage I; figures 1A and 1B). The organizational pattern of C. arabica Stage-I buds is the same as that normally observed in Angiosperm vegetative apices, as described for C.canephora (Moens 1963). Buds at Stage-I are quiescent and undifferentiated and they can form lateral branches (vegetative growth), floral buds (reproductive growth), or stay in the undifferentiated state (Moens, 1963). The developmental route of axillary buds seems to be conditioned to climatic and physiological factors, or to the cultural practices adopted (Moens, 1963; Kumar, 1982). The frequency of secondary lateral branch formation proved to be influenced inversely by the fruit load present in arabica trees (Clowes and Wilson, 1977). After the inductive flowering stimulus, the broadening and raising phenomena of the apical domes appear to be common events largely found in Angiosperms (Esau, 1960; Popham, 1963). Coffee buds with a broad and flat apex were classified as Stage-II buds (figures 1C and 1D). In Stage-II buds, the apical zone has two lateral areas of intense cellular proliferation, in which periclinal cell division predominates. These areas give rise to a second pair of bracts and to the pedicel of the future inflorescence (Dedecca, 1957; Moens, 1963). Moens (1963) stated that the reproductive developmental route in C.canephora becomes irreversible when the apices of induced buds show a typical flat shape. However, Rainer (1946) reported that pruning arabica trees in a region above the induced nodes promoted a reversion to a vegetative route in previously induced buds. The growth and differentiation pattern of lateral regions of flat apices characterize the StageIII buds (figure 2A). The histological pattern of Stage-IV buds is established by the general expansion of bud structures and by the appearance of floral primordia in axils of first pair of bract (figure 2B). In Stage-V buds, the reproductive bud apex, present between leaf projections of the second pair of bracts, begins to develop meristematic regions which will form the future floral buds of the inflorescence (figure 2C). The next recognized phase is Stage-VI buds, which corresponds to the development of sepal and petal primordia on the flanks of meristematic elevated zones of floral bud primordia (figure 2D). The presence of anther primordia defines Stage-VII buds, whereas the presence of ovary primordia characterizes Stage-VIII buds in this histological differentiation pattern (not shown). Stage-IX buds are determined by the presence of all completely defined floral verticilia. The ontogenetic sequence of several floral verticilia in C. arabica is similar to that described for numerous angiosperm species (Deddeca, 1957; Popham, 1963).

Dynamics of histological differentiation: In the region of Campinas (SP, Brazil), vegetative growth of coffee is intense between the months of September and March (warm temperatures and abundant rainfall), but declines from April on, reaching minimum values between June and August (cold temperatures and very low or no rainfall). Barros et al. (1997) concluded that the lowering of temperature is the principal factor responsible for the regulation of seasonal growth in the South-East coffee area in Brazil. The most important flowering sets take place in the month of September (beginning of rainfall season), and they depend on 


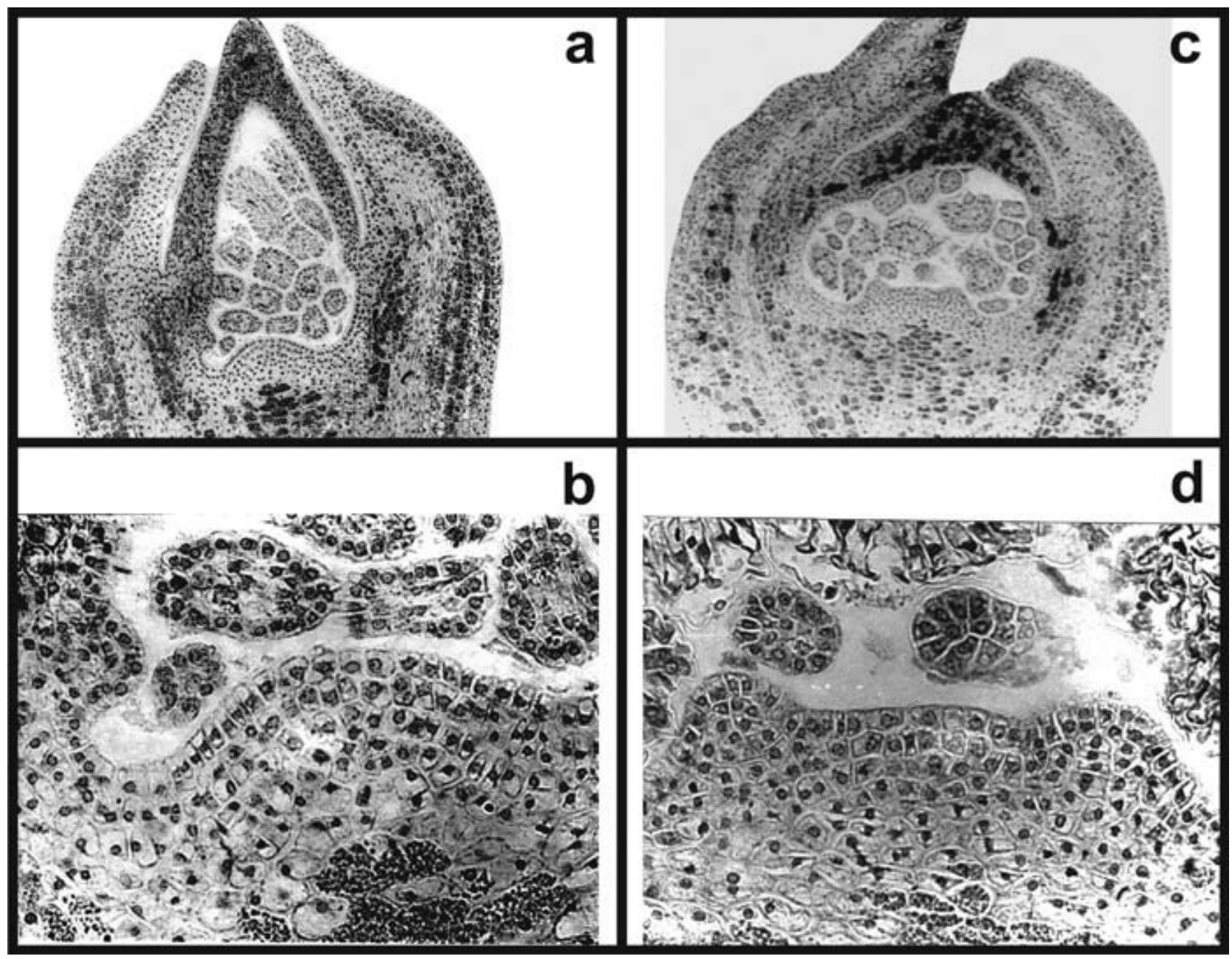

Figure 1. Axial-longitudinal sections of G1-serial buds illustrating the vegetative state (undifferentiated buds; Stage I) and the transition of buds to a reproductive route (Stage II) in C. arabica lateral branches: (A) apex with conical shape situated between foliar primordia typical of Stage I (112 x); (B) detail of vegetative apex showing the bi-serial tunica (448 x); (C) apex with typical flat shape characterizing Stage II of flower bud differentiation (90 x); (D) detail of bud apex at Stage II, with flat and enlarged base showing two lateral groups of dividing cells (448 x).

the presence of axillary buds on at the leaf axils pre-formed since August of the previous year (Majerowicz, 1984). The pin-heads (small, green fruits) are visible in October and November, and increase in size during February and March. Fruit ripening takes place during the months of April and June. Coffee harvest takes place during the months of May to August (figure 3). A detailed phenological standardization for $C$. arabica fruits under Brazilian tropical conditions was recently described by Camargo and Camargo (2001).

During Years I and II of this study, we observed only "1st crop branches" (no pre-existing fruits) which developed during the most recent growth period, i.e. branches originating in August-September of the previous year.
During the months of January and February/Year-I, it was observed that the frequency of undifferentiated buds (Stage I) was progressively reduced until they disappeared totally by beginning of March (figure 4A). In both Years I and II of this study, it was observed that Stage-I type buds had disappeared by early March, when only Stage- II or Stage-III buds were present (figures 4A and 4B). Flower bud differentiation progressed to Stage-IV buds from mid-March onwards. From this phase, the floral bud differentiation process underwent an irreversible and accelerated sequence of events. The overall observations indicated that floral induction and initiation conditions for the reproductive buds of arabica coffee were complete during the months of January and February in both 


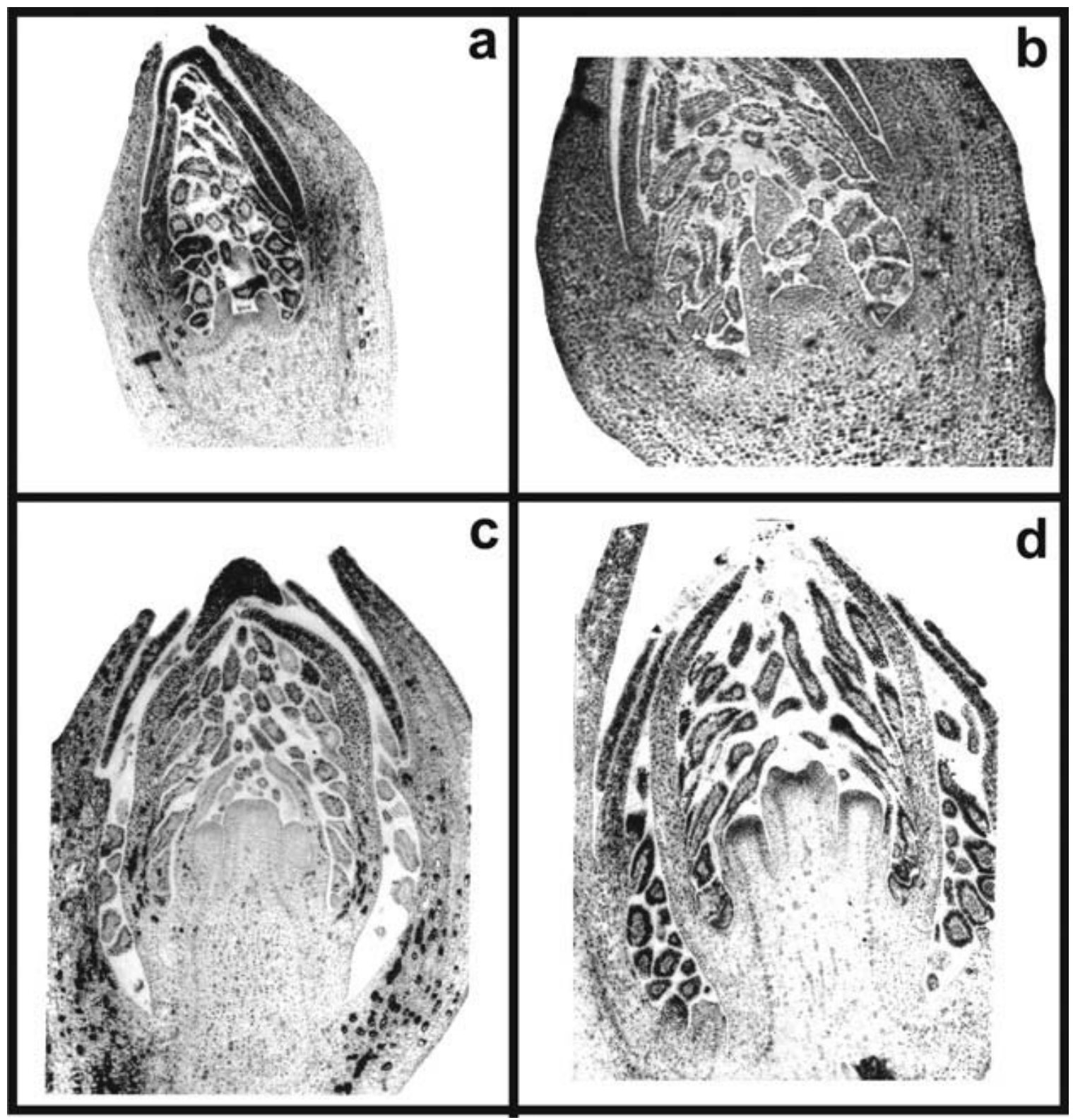

Figure 2. Axial-longitudinal sections of G1 serial buds in process of flower differentiation in C. arabica: (A) Stage-III buds highlighting the primordia of the $2^{\text {nd }}$ pair of bracts originated from cell division at apex lateral regions shown in Figure 1d (45 x); (B) Stage-IV buds, characterized by expansion of flower structures during the differentiation process. Note the development of floral primordia at the axils of the $1^{\text {st }}$ pair of bracts $(56 \mathrm{x})$; (C) Stage-V buds showing floral bud primordia in process of differentiation at the apical region located between the $2^{\text {nd }}$ pair of bracts $(45 \mathrm{x})$; (D) Stage-VI buds identified by the presence of meristematic regions located at the flanks of floral bud primordia, which will give rise to sepals and petals. Two floral primordia are visible in the left axil of the $1^{\text {st }}$ pair of bracts $(45 \mathrm{x})$.

Year I and Year II of this study. The developmental process of floral buds took place very rapidly from the 2nd half of March onwards. It is noteworthy that the endosperm filling phase of fruits was completed in March as well, and fruit ripening began in the month of April. In full sun coffee trees, high-yielding coffee varieties produce elevated amounts of fruits, however without a control mechanism over the total number of fruits being produced. Physiological disturbances, like death of branches (die-back) and bi-annual yields, are the consequence of a lack of a regulatory mechanism on the total number of fruits produced. Cannell $(1971,1974)$ showed that coffee fruits are stronger sinks than the stem 


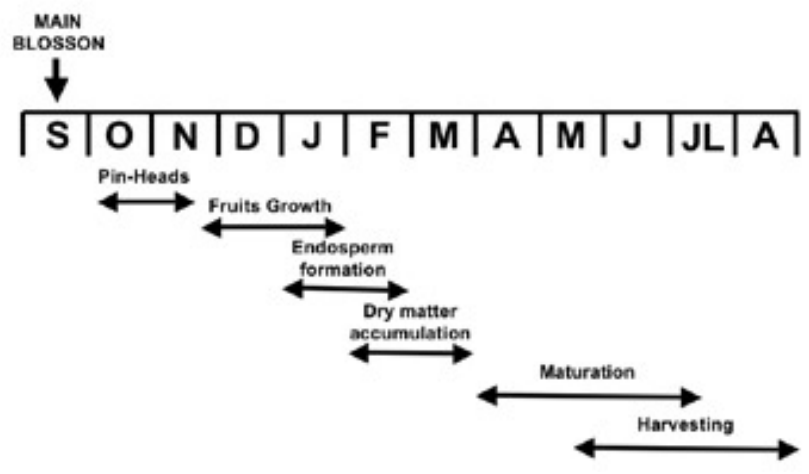

Figure 3. Representative scheme of different phases of coffee reproductive cycle under field conditions in Campinas, SP, Brazil.
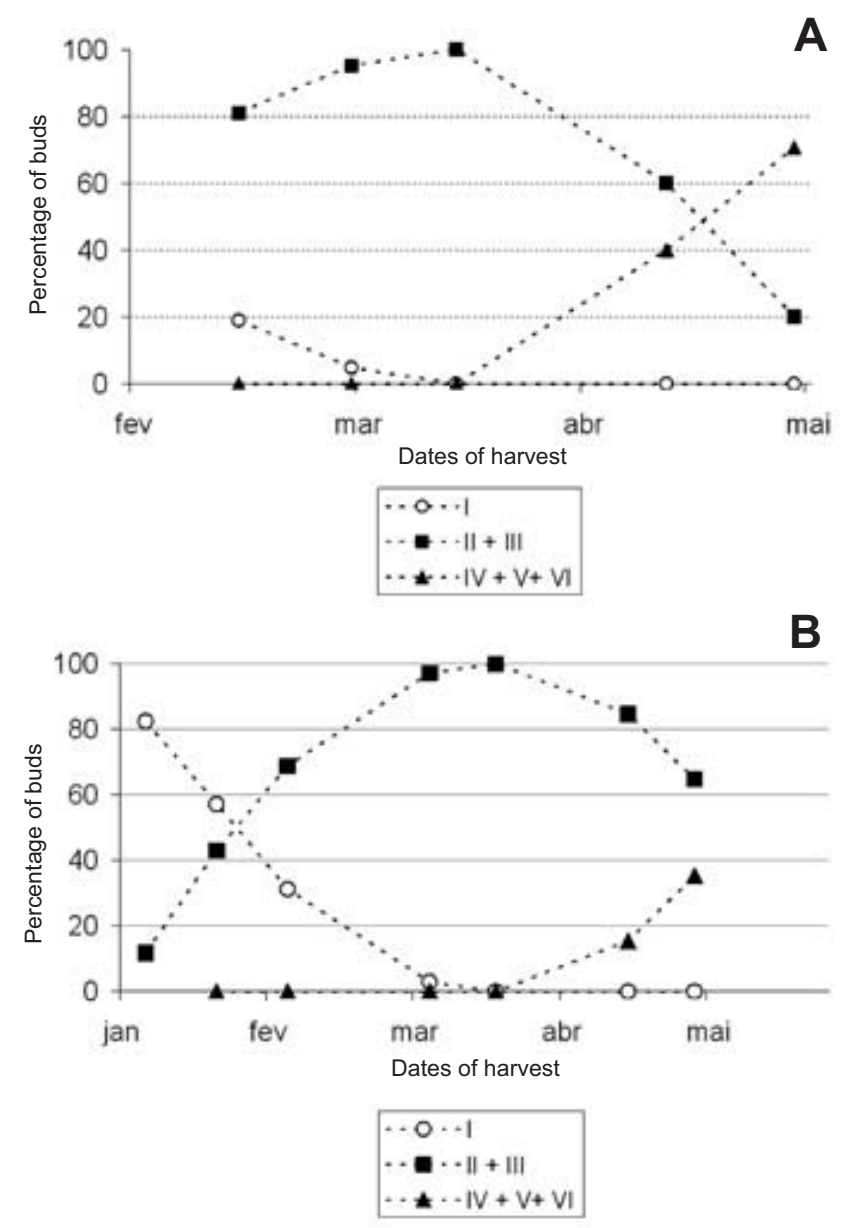

Figure 4. Frequency of buds at different histological differentiating stages in plagiotropic branches located at the third uppermost portion of coffee plants, developed during the most recent growing season: (A) quantitative distribution of floral differentiating stages between February and April of Year-I; (B) quantitative distribution of floral differentiating stages between January and May of Year-II. apices, leading to a significant reduction in vegetative growth during the season of a high bi-annual yield. Changes in the sink-source at the final stage of endosperm storage accumulation, associated with the progressive decline of activity in vegetative apical meristems due to a reduction of air temperature (Barros et al., 1997) and rainfall, could be associated with an intense floral bud differentiation process during the period from April to July.

In "2nd Crop branches," studied in the period between November/Year-III and July/Year-IV, G1 buds located in the 2nd and 3rd node remained at Stage I until the end of April (figure 5A). From April to June, these buds progressively moved to Stage-II and Stage-III. This means that the induction and initiation of these axillary buds took place during the period from April to June, at which time the production of new nodes became progressively slower due to a reduction of vegetative growth (Majerowicz, 1984). This behavior suggests that buds from newly-formed nodes in "2nd crop branches," at the time of intense vegetative growth, were not competent to respond to initiation signals to become reproductive buds. They can be considered as juvenile buds. Moens (1962) reported that the elapsed time between node formation and the initiation of the reproductive bud would depend on the season that the bud was formed, which can vary from 1.8 to 2.3 months. The differentiation of floral buds among axillary buds of 2 nd and 3rd nodes only took place from the second-half of the month of May.

The pattern for floral initiation among buds located at the 4th and 7th node fluctuated between undifferentiated (Stage I) and induced (Stages II and III) during the period of November and end of March. State-I buds were progressively disappearing during April and May (figure 5B). An intense reproductive bud initiation (Stages II and III) was observed in April, but floral bud differentiation was only observed starting early May, a time at which this process assumed intense activity.

The floral bud initiation pattern of buds from the 4th to 7th node of " 2 nd crop branches," (figure 5B) was quite different from the pattern observed in buds of "1st crop branches" (figures 4A and 4B). In the later case, induction and floral initiation occurred during January-February, whereas buds from "2nd crop branches" were already induced in November. Undifferentiated buds (Stage I) and induced buds (Stage II and III) are present in similar proportion between November/Year-III and May/Year-IV. This fact suggests that axillary buds were continuously induced after buds were losing their juvenile state. Once 
buds were initiated to the reproductive path they remained at Stages II and III until the beginning of May, when flower differentiation effectively began. Camayo et al. (2003) studied the dynamics of reproductive development in Chinchina, Colombia (04, 59' N) in terms of morphological characterization of foliar axils and developing floral buds. These authors verified that the differentiation of reproductive structures occurred continuously at that location, since they found all stages of floral bud differentiation throughout the year. However, a greater frequency of reproductive buds at certain times of the year was attributed to external factors that promote vegetative growth (new nodes and new axillary buds), mainly optimum rainfall and high irradiation.

The presence of developing fruits in " 2 nd crop branches" (where fruits were present at older nodes) apparently caused a delay of one-half month for the beginning of the floral bud differentiation process in comparison to " 1 st crop branches" (branches without fruits). In the case of " 2 nd crop branches"

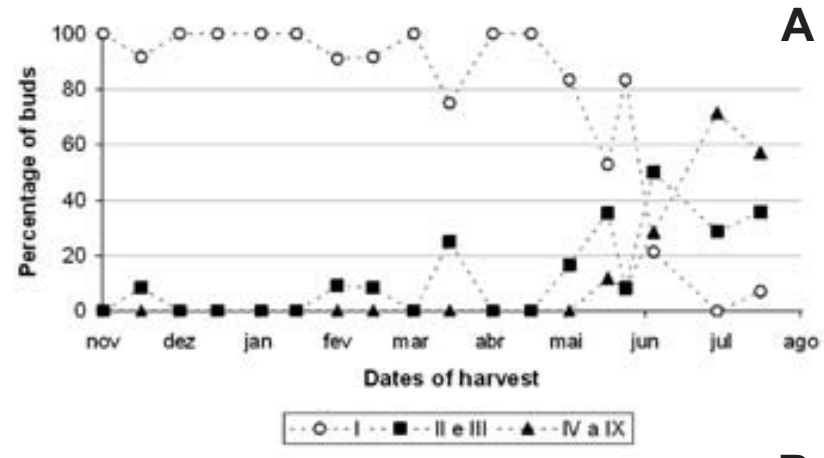

B

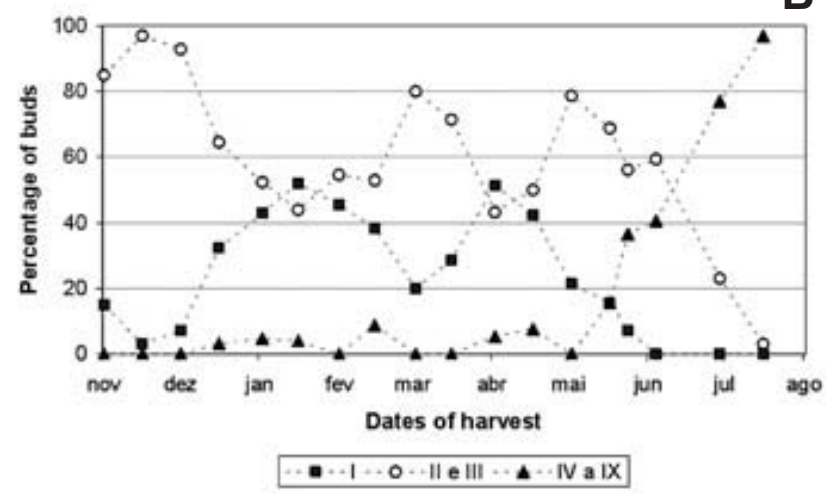

Figure 5. Frequency of buds at different histological differentiating stages between November Year-III and July Year-IV in plagiotropic branches developed in the previous growing season. These branches were located in the middle portion of the plant, bearing fruits in their old leaf axil nodes: (A) buds located in the $2^{\text {nd }}$ and $3^{\text {rd }}$ leaf pair from the branch apex; (B) buds located between the $4^{\text {th }}$ and $7^{\text {th }}$ leaf pair from the branch apex. (branches with fruits), the activity of floral bud differentiation became intense after fruit harvesting during the 2nd week of May. According to Wormer and Gituanja (1970a,b), the presence of fruits appears to promote an inhibitory action on floral bud differentiation up to harvest time. In Kenya, Cannell (1972) observed that the time at which the majority of floral primordia are were formed coincided with the seasonal patterns of vegetative growth and fruit formation. Womer and Gituanja (1970a,b) concluded that the reproductive cycle of coffee plants is closely related to its vegetative cycle, and a particular flowering pattern cannot be isolated from the intrinsic conditions of a plant (age, nutritional state and production). On the other hand, the synchronization of a group of plants within vegetative and reproductive patterns seems to depend on the rainfall distribution in equatorial regions (Trojer, 1968; Womer and Gituanja, 1970 a).

The results of this histological study clearly show a different behavior for floral induction and differentiation in arabica coffee according with the presence or absence of fruits on the branches, as summarized below:

\begin{tabular}{lll}
\hline & Induction & $\begin{array}{l}\text { Beginning of } \\
\text { differentiation }\end{array}$ \\
\hline $\begin{array}{l}\text { 1st crop branches } \\
\text { (no fruits) }\end{array}$ & January - February & March - April \\
\hline $\begin{array}{l}\text { 2nd crop branches } \\
\text { (with fruits) }\end{array}$ & October - July & $\begin{array}{l}\text { May } \\
\text { (after harvest) }\end{array}$ \\
\hline
\end{tabular}

In arabica coffee growing under field conditions in the region of Campinas (SP, Brazil), the regulatory signals for induction and initiation of reproductive buds are different from signals controling controlling the differentiation of floral buds. In "1st crop branches" (no fruits) the initiation of reproductive buds took place during January - February. Axillary buds of "2nd crop branches" (with fruits) were induced and initiated initial stages of reproductive growth throughout every month of this study (October - July), i.e. during spring, summer, and fall seasons. Timing for floral bud differentiation seems to be strongly influenced by fruit development on the plant (total production) and by adjacent fruits within the same branch. In "1st crop branches" (no fruits), located in the upper third portion of coffee plants, floral bud differentiation coincided with the final stage of endosperm dry mass accumulation of fruits (March - April). In contrast, "2nd crop branches" with fruits at older nodes differentiated their floral buds only after fruit harvesting (after the month of May in this study). 


\section{REFERENCES}

Barros RS, Maestri M, Coons MP (1978) The physiology of flowering in coffee: a review. J. Coffee Res. 8:29-73.

Barros RS, Mota JWS, DaMatta FM, Maestri M (1997) Decline of vegetative growth in Coffea arabica $\mathrm{L}$. in relation to leaf temperature, water potential and stomatal condutance. Field Crops Res. 54:65-72.

Bernier G (1988) The control of floral evocation and morphogenesis. Annu. Rev. Plant Physiol. Plant Mol. Biol. 39:175-219.

Bernier G, Havelange A, Houssa C, Petitjean A, Lejeune P (1993) Physiological signals that induce flowering. Plant Cell 5:1147-1155.

Boyer J (1969) Étude Expérimentales des effects du régime d' humidité du sol sur la croissance végétatif, la floraison e la fructificacion des caféiers robusta. Café Cacao Thé 13:187-200.

Camargo AP, Camargo MBP (2001) Definição e esquematização das fases fenológicas do cafeeiro arábica nas condições tropicais do Brasil. Bragantia 60:65-68.

Camayo VGC, Chaves CB, Arcila PJ, Jaramillo R (2003) Desarrollo floral del cafeto y su relación con las condiciones climáticas de Chinchiná-Caldas. Cenicafé 54:35-49.

Cannell MGR (1971) Production and distribution of dry matter in trees of Coffea arabica L. in Kenya as affected by seasonal climatic differences and the presence of fruits. Ann. Appl. Biol. 67:99-120.

Cannell MGR (1972) Photoperiodic response of mature trees of arabica coffee. Turrialba 22:198-206.

Cannell MGR (1974) Factors affecting arabica coffee bean size in Kenya. J. Hort. Sci. 49: 65-76.

Clowes MStJ, Wilson JHH (1977) The growth and development of lateral branches of Coffea arabica L. in Rhodesia. Rhod. J. Agric. Res. 15:171-185.

Dedecca DM (1957) Anatomia e desenvolvimento ontogenético de Coffea arabica L. variedade Typica Cramer. Bragantia 16:315-366.

Esau K (1960) Anatomy of seed plants. Wiley, New York.

Franco CM (1940) Fotoperiodismo em cafeeiro (Coffea arabica L.). Rev. Inst. Café, São Paulo, 27:1586-1592.

Fosket DE (1994) Plant growth and development. A molecular approach. Academic Press, California.

Jacskon DI, Sweet GB (1972) Flower initiation in temperate woody plants (A review based largely on the literature of conifers and deciduous trees). Hort. Abstr. 42:9-24.
Kumar D (1982) Primary investigations into some flowering abnormalities of coffee in Kenya. Kenya Coffee 47: 16-24.

Labouriau LG (1969) Flower initiation in Vicia graminea Sm. Ann. Acad. Bras. Cienc. 41:453-469.

Majerowicz N (1984) Estudo da diferenciação e crescimento de gemas florais de Coffea arabica L. Observações sobre antese e maturação de frutos. Campinas (SP, Brazil), Universidade Estadual de Campinas. MSc thesis.

McDaniel CN (1996) Developmental physiology of floral initiation in Nicotiana tabacum L. J. Exp. Bot. 47:465-475.

McDaniel CN, Singer SR, Smith SME (1992) Developmental states associated with floral transition. Dev. Biol. 153: 59-69.

Moens P (1962) Étude écologique du développment génératif et végétatif des bourgeons de Coffea canephora Pierre (L' initiation florale). Institut Nacional pour l'étude Agronomique du Congo (INEAC), 103 p. Serie Scientifique 96.

Moens P (1963) Les bourgeons végétatifs et génératifs de Coffea canephora Pierre. (Étude morphologique et morphogénetique). La Cellule 63:165-244.

Piringer AA, Borthwick HA (1955) Photoperiodic response of coffee. Turrialba 5:72-77.

Popham RA (1963) Developmental studies of flowering. Columbus, Ohio State University. Paper 687:138-156.

Rainer RW (1946) Growth and bearing habits of Coffea arabica L. in Kenya and Southern India. Expl. Afr. Agric J. 11:251-255.

Thomas B, Vince-Prue D (1997) The Physiology of photoperiodic floral induction. In: Photoperiodism in Plants, pp. $143-179,2^{\text {nd }}$ ed., Academic Press, London.

Trojer H (1956) La investigacion agroclimatológica para el cultivo del café in Colombia. Boletin Informativo Cenicafé 7:78-101.

Went FW (1957) The experimental control of plant growth. Chronica Botanica 17.

Wormer TM, Gituanja J (1970a) Floral initiation and flowering of Coffea arabica L. in Kenya. Expl. Agric. 6:157-170.

Wormer TM, Gituanja J (1970b). Seasonal patterns of growth and development of arabica coffee in Kenya. Kenya Coffee 35:270-277.

Zeevaart JAD (1976) Physiology of flower formation. Annu. Rev. Plant Physiol. 27:321-348. 